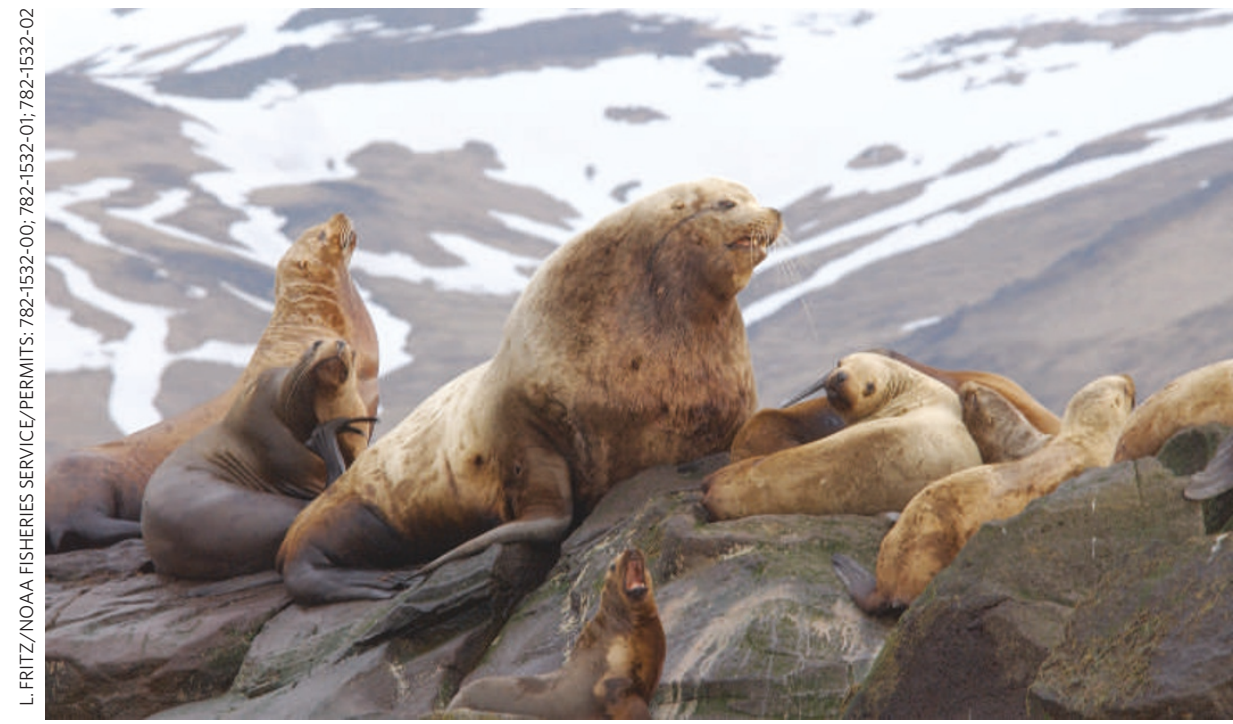

A programme to save Steller sea lions has been criticized for using hot brands on pups.

\section{Animal-rights group sues over 'disturbing' work on sea lions}

Fresh allegations have surfaced about an extensive US research programme designed to save endangered sea lions. The charges say it may actually be harming the species.

On 12 July the Humane Society of the United States sued the National Marine Fisheries Service (NMFS), saying that it failed to properly conduct and monitor studies on Steller sea lions (Eumetopias jubatus) in Alaska.

The lawsuit alleges that the NMFS violated animal-protection laws "by issuing multiple research permits to a wide variety of entities that allow intrusive, duplicative, uncoordinated and unnecessary research on Steller sea lions".

The records of the US Marine Mammal Commission, an independent panel that oversees research, partly support the society's allegations. William Hogarth, a top official at the NMFS, wrote in a letter to the society on 22 June that he also has concerns.

Hogarth has ordered an extensive environmental study on the Steller research programme, which is expected to take two years and may cost up to $\$ 500,000$. The NMFS has pumped more than $\$ 120$ million over the past four years into research on why Steller populations have plunged in the past quarter-century (see Nature 436, 14-16; 2005).

Administrators of the Steller research programme say the studies are conducted appropriately, with only one or two animal deaths annually. "No one is doing anything that is not important for research," says Douglas DeMaster, an NMFS biologist and director of the Alaska Fisheries Science Center in Seattle.

In May and June the NMFS issued research permits before a review period required by the Marine Mammal Commission was complete. "This is particularly disturbing in light of the scope of the proposed research and potential for adverse effects," wrote David Cottingham, the commission's executive director, in a letter to the NMFS on 10 June.

The commission has regularly questioned aspects of Steller research, citing the hot branding' of hundreds of pups, the sedation of animals, and the lack of follow-up reports on previous studies, among other factors.

One researcher seeking a permit this year was Randall Davis, a physiologist at Texas A\&M University, Galveston. On 31 May, Davis was cited for alleged research violations in 2003 and 2004. He faces a $\$ 10,000$ fine and research restrictions after his team reportedly used an unapproved sedation drug and captured Stellers in violation of his research permit.

Davis is contesting the charges, and an administrative hearing is planned. He told Nature that some NMFS officials were "completely out of control", adding that they were "hostile to researchers".

NMFS officials say they are discussing the concerns with the Humane Society. A society attorney says that if no remedy turns up, he will seek a court order to suspend some projects. Rex Dalton
ON THE RECORD

'CAll I can say is 'shucks'. We ran out of gas."

Wayne Hale, deputy manager of the US space shuttle programme, reacts to the postponement of the shuttle's launch due to a faulty fuel sensor.

\section{SCORECARD}

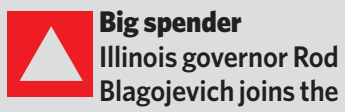

biotech bandwagon with a decision to spend $\$ 10$ million on stem-cell research.

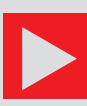

Fight club

Thai officials plan 'passports' for fighting cocks in effort to track bird flu's spread through pugilistic poultry.

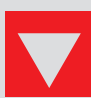

\section{Where's the beef?} Reality bites for Canadian cows as a court ruling overturns objections to US plan to import beef from up north.

\section{NUMBER CRUNCH}

\section{8 miles How far the} average UK resident drives every year to shop for food.

\section{9 million tonnes The} amount of carbon dioxide emitted in Britain in 2002 transporting food to the dinner table.

$\$ 15.5$ billion The minimum annual cost to Britain of these 'food miles'.

Source: UK Department for Environment, Food and Rural Affairs.

\section{OVERHYPED}

\section{Alcoholism treatments}

'Talk' therapies, such as the 12step programme, are commonly used to help alcoholics give up their vice - but do they really work? A 1997 study suggested that they offered unequivocal benefits, but a reanalysis of the original data is casting a somewhat different light.

Although alcoholics who finished a course of treatment did well, those who dropped out of the course before it started were almost as successful at curing their cravings. Those who did worst were those who quit therapy after a single session, suggesting that secret to success is more will power than therapy. 